\title{
Distribution of trans-vaccenic acid and cis9,trans11- conjugated linoleic acid (rumenic acid) in blood plasma lipid fractions and secretion in milk fat of Jersey cows fed canola or soybean oil
}

\author{
Juan J. LoOR, Lora E. QuINLAN, Aloka B.P.A. BANDARA, \\ Joseph H. HERBEIN*
}

Dairy Science Department, Virginia Tech, Blacksburg, VA, 24061-0315, USA

(Received 25 September 2001; accepted 29 April 2002)

\begin{abstract}
To determine fatty acid distribution in lipid fractions of bovine blood plasma, 24 multiparous Jersey cows at peak lactation were fed a control diet (no supplemental oil, NOS) or the control diet supplemented at $35 \mathrm{~g} \cdot \mathrm{kg}^{-1}$ dry matter with canola oil (CAN), soybean oil (SOY), or a mixture of equal amounts of canola and soybean oil (MIX) for $4 \mathrm{wk}$. Plasma lipid fractions were isolated with aminopropyl columns. Fatty acid concentration in the phospholipid (PL), cholesterol ester (CE), and triglyceride (TG) fractions of plasma from cows fed supplemental oil was $142(+47 \%), 144$ $(+57 \%)$, and $26(+72 \%) \mu \mathrm{g} \cdot \mathrm{mL}^{-1}$ greater than those of the control group. Oleic acid increased from 153 to 195,100 to 151,35 to 53 , and 103 to $161 \mathrm{mg} \cdot \mathrm{g}^{-1}$ of total fatty acids in the free fatty acid (FFA), PL, CE, and TG fractions, respectively, when CAN-fed cows were compared with NOS. In contrast, SOY intake increased 18:2n-6 in FFA, PL, CE, and TG fractions from 37 to 55,327 to 366,684 to 744 , and 42 to $72 \mathrm{mg} \cdot \mathrm{g}^{-1}$, respectively. In the TG fraction, feeding SOY also increased trans 11-18:1 from 40 to $105 \mathrm{mg} \cdot \mathrm{g}^{-1}$ and cis 9 ,trans $11-18: 2$ from 1 to $12 \mathrm{mg} \cdot \mathrm{g}^{-1}$. Concentration and yield of trans $11-18: 1$ in milk fat were $21 \mathrm{mg} \cdot \mathrm{g}^{-1}$ and $13.7 \mathrm{~g} \cdot \mathrm{d}^{-1}$ when feeding NOS, and increased to $45 \mathrm{mg} \cdot \mathrm{g}^{-1}$ and 43.1 $\mathrm{g} \cdot \mathrm{d}^{-1}$ in response to SOY. Similarly, concentration and yield of cis 9 , trans $11-18: 2$ were $5 \mathrm{mg} \cdot \mathrm{g}^{-1}$ and $7.3 \mathrm{~g} \cdot \mathrm{d}^{-1}$, and increased to $13 \mathrm{mg} \cdot \mathrm{g}^{-1}$ and $11.2 \mathrm{~g} \cdot \mathrm{d}^{-1}$ in response to SOY. Concentrations of trans-isomers in blood plasma and milk fat ranked by treatment reflected linoleic acid intakes, and were greater in SOY-fed cows compared with NOS or CAN-fed cows. Plasma lipid fractions can be used to appraise incomplete biohydrogenation of unsaturated fatty acids in the rumen.
\end{abstract}

rumenic acid / trans-vaccenic acid / bovine plasma / milk fat

* Correspondence and reprints

Tel.: 540-231-4766; fax: 540-231-5014; e-mail: herbeinj@vt.edu 
Résumé - Distribution de l'acide trans-vaccénique et de l'acide linoléique conjugué cis9, trans 11 (acide ruménique) dans les fractions lipidiques du plasma sanguin et leur sécrétion dans la matière grasse du lait de vaches de race Jersiaise nourries à l'huile de canola et de soja. Afin de déterminer la distribution des acides gras dans les fractions lipidiques du plasma sanguin de bovins, 24 vaches multipares de race Jersiaise au pic de lactation ont reçu soit un régime témoin (sans addition d'huile, NOS) soit un régime témoin supplémenté de $35 \mathrm{~g} \cdot \mathrm{kg}^{-1}$ de matière sèche d'huile de canola (CAN) ou d'huile de soja (SOY), soit un mélange en quantité égale d'huile de canola et de soja (MIX) sur une période de 4 semaines. Les fractions lipidiques du plasma ont été isolées sur colonnes aminopropyle. La concentration en acides gras dans les fractions phospholipides (PL), esters de cholestérol (CE) et triglycérides (TG) du plasma a été, respectivement, plus élevée de 142 (+47\%), 144 $(+57 \%)$, et $26(+72 \%) \mu \mathrm{g} \cdot \mathrm{mL}^{-1}$ chez les vaches recevant un régime enrichi en huile. Par rapport au témoin, l'acide oléique a augmenté de 153 à 195 , de 100 à 151 , de 35 à 53 , et de 103 à $161 \mathrm{mg} \cdot \mathrm{g}^{-1}$ d'acides gras totaux dans les fractions acides gras libres (FFA), PL, CE, et TG, respectivement, lorsque les vaches étaient alimentées avec le régime CAN. L'ingestion du régime SOY a augmenté la concentration du 18:2 n-6 dans les fractions FFA, PL, CE, et TG de 37 à 55, de 327 à 366, de 684 à 744 , et de 42 à $72 \mathrm{mg} \cdot \mathrm{g}^{-1}$, respectivement, alors que dans la fraction TG, le régime SOY a augmenté les concentrations du trans 11-18:1 de 40 à $105 \mathrm{mg} \cdot \mathrm{g}^{-1}$ et du cis 9 , trans 11-18:2 de 1 à $12 \mathrm{mg} \cdot \mathrm{g}^{-1}$. La concentration et la sécrétion du trans 11-18:1 dans la matière grasse du lait ont été de $21 \mathrm{mg} \cdot \mathrm{g}^{-1}$ et $13,7 \mathrm{~g} \cdot \mathrm{j}^{-1}$ avec le régime NOS, et ont atteint $45 \mathrm{mg} \cdot \mathrm{g}^{-1}$ et $43,1 \mathrm{~g} \cdot \mathrm{j}^{-1}$ avec le régime SOY. De même, la concentration et la sécrétion du cis 9 , trans $11-18: 2$ ont été de $5 \mathrm{mg} \cdot \mathrm{g}^{-1}$ et $7,3 \mathrm{~g} \cdot \mathrm{j}^{-1}$, et ont culminé jusqu'à $13,0 \mathrm{mg} \cdot \mathrm{g}^{-1}$ et $11,2 \mathrm{~g} \cdot \mathrm{j}^{-1}$ en réponse au régime SOY. Entre traitements, les concentrations des isomères trans dans le plasma sanguin et la matière grasse du lait ont reflété les ingestions d'acide linoléique, et ont donc été plus importantes chez les vaches recevant le régime SOY comparées à celles du régime NOS ou CAN. Les fractions lipidiques du plasma peuvent être utilisées pour apprécier la composition en produits de la bio-hydrogénation des acides gras insaturés dans le rumen.

\section{acide ruménique/ acide trans-vaccénique / plasma / matière grasse du lait / bovin}

\section{INTRODUCTION}

The concentration of blood plasma lipid fractions in ruminants fed supplemental fat is elevated $[5,28]$. However, plasma fatty acid profiles of cattle and sheep do not necessarily reflect dietary fatty acid content. During hydrogenation in the rumen, isomerization of $18: 2 n-6$ results in production of cis9,trans11-18:2 (CLA) [15]. Trans 11-18:1 and 18:0, however, are the primary products from $18: 2 n-6$ or $18: 3 n-3$ hydrogenation $[15,33]$. Oleic acid was either not hydrogenated [14], isomerized to trans 11-18:1 (5\% of total oleic acid substrate), or hydrogenated directly to $18: 0$ (80-90\% of total oleic acid substrate) [23].

Under normal conditions, polyunsaturated fatty acids in blood plasma of sheep appear to be selectively incorporated into the plasma cholesterol ester (CE) and phospholipid (PL) fractions [26]. When soybean oil was fed to dairy cows [19] the proportion of $18: 2 n-6$ in the PL and CE fractions increased. Stearic acid concentration, however, was higher in the triglyceride (TG) fraction. Similarly, proportions of 18:0 and 18:1 (cis and trans isomers were not separated) fatty acids in milk fat also were increased. More recently, ruminal infusion of canola oil (200 to $400 \mathrm{~g} \cdot \mathrm{d}^{-1}$ for $14 \mathrm{~d})$ resulted in higher concentrations of 18:0 and trans 11-18: 1 in blood plasma and milk TG [6].

Unsaturated oil feed ingredients are widely used in contemporary diets for lactating cows, and they can have a profound effect on the manufacturing and nutritional properties of milk fat $[2,29]$. A significant portion of esterified fatty acids in milk fat are derived from plasma TG and nonesterified fatty acids FFA [30], and to a 
lesser extent phospholipids PL [38], extracted by the mammary gland. Although several studies have previously evaluated fatty acid composition in selected plasma lipid fractions due to feeding lipid supplements to lactating dairy cows none, to our knowledge, reported responses in trans 1118:1 and cis9,trans 11-18:2 systematically. Lipid fractions in ruminant plasma have traditionally been isolated using thin-layer chromatography $[17,19,21,26,28]$. This procedure, however, is relatively slow, may result in oxidation of polyunsaturated fatty acids due to extensive exposure to air, and produces low lipid recoveries [13, 22].

In the present study, we utilized solid-phase extraction column chromatography as an alternative to thin-layer chromatography (TLC) for isolation of plasma lipid fractions. This procedure reportedly improved lipid recovery, sample throughput, and may reduce the risk of fatty acid oxidation compared with TLC [13]. Diets contained either canola oil, soybean oil, or equal amounts of canola plus soybean oil to vary the amount of oleic acid, linoleic acid, cis9, trans 11-18:2, and trans11-18:1 flowing from the rumen to the small intestine for absorption and incorporation into plasma lipid fractions. The overall objective of the study was to determine changes in the profiles of lipid fractions due to dietary treatments imposed. Of particular interest was to examine relationships between intake of oleic and linoleic acid, profiles of trans 11-18:1 and cis 9, trans 11-18:2 in blood plasma, and secretion of both biohydrogenation intermediates in milk fat.

\section{MATERIALS AND METHODS}

\subsection{Animals and diets}

Twenty-four Jersey cows between 60 and $90 \mathrm{~d}$ postpartum were housed in a free stall barn and individually fed a total mixed diet without supplemental oil for ad libitum intake using a Calan feeding system (American Calan, Inc., Northwood, NH, USA) for $7 \mathrm{~d}$ before the study. After the 7-d adjustment period, cows were randomly assigned to a diet (Tab. I) containing no supplemental oil (NOS, control) or diets in which corn grain in NOS was replaced $\left(35 \mathrm{~g} \cdot \mathrm{kg}^{-1}\right.$ dry matter) with canola oil (CAN), soybean oil (SOY), or an equal mixture of canola (17.5 $\mathrm{g} \cdot \mathrm{kg}^{-1}$ dry matter) and soybean oil (17.5 $\mathrm{g} \cdot \mathrm{kg}^{-1}$ dry matter) (MIX) for $4 \mathrm{wk}$. Diets were prepared daily and fed at 17:00 h. Feed allotment was calculated to allow 5 to $10 \%$ feed refusal. Diets were formulated using Dair4 [36] to meet nutrient requirements of lactating cows producing $23 \mathrm{~kg}$ milk and consuming $17 \mathrm{~kg}$ dry matter daily [27]. Water was available in the free stall barn at all times. Cows were milked each day at 13:00 and 01:00 h. Animal management and sampling procedures were approved by the Virginia Polytechnic Institute and State University Animal Care Committee.

\subsection{Blood plasma collection, lipid extraction, and fatty acid analysis}

Jugular blood samples (20 mL) were obtained by venipuncture on $\mathrm{d} 7$ of the adjustment period and d 28 of the experimental period at $4 \mathrm{~h}$ after feeding. The concentrations of bovine plasma lipid fractions do not have a circadian rhythm when cows consume feed ad libitum [4]. The constant rate of passage of lipids from the rumen prevents abrupt increases in plasma fatty acids. Blood was transferred to tubes containing $286 \mathrm{IU}$ heparin in $100 \mu \mathrm{L}$ of sterile saline, and centrifuged at $3000 \times g$ for $15 \mathrm{~min}$ at $4{ }^{\circ} \mathrm{C}$ for harvesting plasma. Plasma was stored at $-20{ }^{\circ} \mathrm{C}$ until lipid extraction and fatty acid analysis.

Lipids were extracted from plasma with chloroform/methanol (2:1, vol/vol). Subsequently, blood plasma lipid fractions were separated using Bond Elut ${ }^{\circledR}$ aminopropyl disposable columns $(500 \mathrm{mg})$ with stainless 
Table I. Ingredient and chemical composition of diets.

\begin{tabular}{|c|c|c|c|c|}
\hline & NOS & CAN & MIX & SOY \\
\hline Ingredient & \multicolumn{4}{|c|}{$\mathrm{g} \cdot \mathrm{kg}^{-1}$ dry matter } \\
\hline Alfalfa haylage & 325 & 325 & 325 & 325 \\
\hline Corn silage & 253 & 253 & 253 & 253 \\
\hline Corn grain & 327 & 292 & 292 & 292 \\
\hline Soybean meal, $48 \%$ crude protein & 59 & 59 & 59 & 59 \\
\hline Canola oil & 0 & 35 & 17.5 & 0 \\
\hline Soybean oil & 0 & 0 & 17.5 & 35 \\
\hline Prolak $^{1}$ & 22 & 22 & 22 & 22 \\
\hline Mineral/vitamin $\operatorname{mix}^{2}$ & 14 & 14 & 14 & 14 \\
\hline \multicolumn{5}{|l|}{ Chemical composition } \\
\hline NDF & 293 & 288 & 288 & 288 \\
\hline $\mathrm{ADF}$ & 195 & 193 & 193 & 193 \\
\hline Crude protein & 168 & 163 & 163 & 163 \\
\hline \multirow[t]{2}{*}{ Total fatty acids ${ }^{3}$} & 35 & 61 & 63 & 64 \\
\hline & \multicolumn{4}{|c|}{$\mathrm{mg} \cdot \mathrm{g}^{-1}$ total fatty acids } \\
\hline $14: 0$ & 6 & 4 & 3 & 4 \\
\hline $16: 0$ & 183 & 112 & 130 & 146 \\
\hline 18:0 & 24 & 24 & 29 & 32 \\
\hline cis9-18:1 & 170 & 473 & 328 & 185 \\
\hline $18: 2 n-6$ & 481 & 303 & 411 & 520 \\
\hline $18: 3 n-3$ & 136 & 84 & 99 & 113 \\
\hline
\end{tabular}

${ }^{1}$ Prolak (H.J. Baker \& Bro., Inc., Atlanta, GA, USA): crude protein $=600 \mathrm{~g} \cdot \mathrm{kg}^{-1}$ dry matter, crude fat $=60 \mathrm{~g} \cdot \mathrm{kg}^{-1}$ dry matter, crude fiber $=20 \mathrm{~g} \cdot \mathrm{kg}^{-1}$ dry matter.

2 Mineral/vitamin mix (Southern States Cooperative, Richmond, VA, USA): salt $\left(38-48 \mathrm{~g} \cdot \mathrm{kg}^{-1}\right), \mathrm{NaHCO}_{3}$ $\left(180 \mathrm{~g} \cdot \mathrm{kg}^{-1}\right), \mathrm{Ca}\left(145-174 \mathrm{~g} \cdot \mathrm{kg}^{-1}\right), \mathrm{P}\left(65 \mathrm{~g} \cdot \mathrm{kg}^{-1}\right), \mathrm{Cl}\left(58 \mathrm{~g} \cdot \mathrm{kg}^{-1}\right), \mathrm{S}\left(32 \mathrm{~g} \cdot \mathrm{kg}^{-1}\right), \mathrm{Mg}\left(22 \mathrm{~g} \cdot \mathrm{kg}^{-1}\right), \mathrm{K}\left(35 \mathrm{~g} \cdot \mathrm{kg}^{-1}\right)$, Mn (1 g kg $\left.{ }^{-1}\right), \mathrm{Zn}\left(1 \mathrm{~g} \cdot \mathrm{kg}^{-1}\right)$, Fe $\left(0.3 \mathrm{~g} \cdot \mathrm{kg}^{-1}\right), \mathrm{Cu}\left(0.1 \mathrm{~g} \cdot \mathrm{kg}^{-1}\right)$, I $\left(0.02 \mathrm{~g} \cdot \mathrm{kg}^{-1}\right)$, Co $\left(0.003 \mathrm{~g} \cdot \mathrm{kg}^{-1}\right)$, Se $\left(0.005 \mathrm{~g} \cdot \mathrm{kg}^{-1}\right), \mathrm{F}\left(0.65 \mathrm{~g} \cdot \mathrm{kg}^{-1}\right)$, retinyl acetate $\left(0.36 \mathrm{~g} \cdot \mathrm{kg}^{-1}\right)$, cholecalciferol $\left(0.01 \mathrm{~g} \cdot \mathrm{kg}^{-1}\right)$, dl- $\alpha$-tocopherol acetate $\left(0.59 \mathrm{~g} \cdot \mathrm{kg}^{-1}\right)$.

${ }^{3}$ Sum of $14: 0$ to $18: 3 n-3$.

steel frits in a Vac Elut ${ }^{\circledR}$ vacuum elution apparatus (Analytichem International, Harbor City, CA, USA) [13]. Samples were transmethylated with $0.5 \mathrm{~N}$ methanolic $\mathrm{NaOH}$ at $50{ }^{\circ} \mathrm{C}$ for $30 \mathrm{~min}$, followed by $14 \%$ boron trifluoride in methanol also at $50{ }^{\circ} \mathrm{C}$ for $30 \mathrm{~min}$ [32]. Methyl esters of fatty acids were separated by gas chromatography using a $30 \mathrm{~m} \times 0.25 \mathrm{~mm}$ i.d. fused silica capillary column (SP-2380, Supelco, Inc., Bellefonte, PA, USA). Pure methyl ester standards (Nu-Check Prep, Elysian, MN, USA; Supelco, Inc., Bellefonte, PA, USA) were used to identify peaks, and determine correction factors for individual fatty acids.
The injector temperature was maintained at $225^{\circ} \mathrm{C}$ and the detector temperature at $275^{\circ} \mathrm{C}$. The initial column temperature was $205^{\circ} \mathrm{C}$ (held for $12 \mathrm{~min}$ ), and was programmed to increase $2^{\circ} \mathrm{C} \cdot \mathrm{min}^{-1}$ to a final temperature of $220^{\circ} \mathrm{C}$ (held for $2 \mathrm{~min}$ ).

\subsection{Sampling, measurements, and chemical analysis of diets}

Milk production was recorded electronically at each milking throughout the study. At wk 0 and 4, two $30 \mathrm{~mL}$ aliquots of milk were collected at 01:00 and 13:00 h. A $30 \mathrm{~mL}$ aliquot was collected in a $50 \mathrm{~mL}$ vial 
containing Bronopol (milk preservative; D \& F Control Systems, San Ramon, CA, USA) immediately after milking. Milk was analyzed for milk fat, protein, lactose, and solids-not-fat by infrared analysis with a 4-channel spectrophotometer (Virginia Dairy Herd Improvement Association, VA, USA). An additional aliquot of milk without Bronopol also was collected, then frozen at $-20^{\circ} \mathrm{C}$. Subsequently, samples were thawed at room temperature and centrifuged at $10000 \times g$ for $1 \mathrm{~h}$ to isolate milk fat. Methylation and chromatographic separation of fatty acids in milk fat were as described for blood plasma.

Forages and concentrate were sampled during the last day of each experimental wk. Samples were dried in a forced-air oven at $60{ }^{\circ} \mathrm{C}$, then stored in sealed plastic containers. Equal amounts of samples from each wk were combined to determine chemical composition. In preparation for analyses, dried forages and concentrate were ground first through a $2 \mathrm{~mm}$ screen (Thomas-Wiley Laboratory Mill), then through a $1 \mathrm{~mm}$ screen in a Cyclotec mill (Tecator 1093, Hoganas, Sweden). Forages and concentrates were analyzed for acid detergent fiber and neutral detergent fiber [40] and total nitrogen [1]. Lipid extraction, methylation, and chromatographic separation of fatty acids in forages and concentrates were as described for blood plasma.

\subsection{Statistical analysis}

Data were analyzed by analysis of covariance using the MIXED procedure of SAS [34], with observations at the end of the adjustment period serving as covariate for observations at $28 \mathrm{~d}$. Data for fatty acid concentrations in plasma lipid fractions, dry matter intake, and fatty acid intake are presented as Least squares means with pooled SEM. Data for milk production and composition, and fatty acid profiles of milk fat were reported previously [2]. The model for statistical analysis of all data in- cluded: covariate adjustment, treatment (NOS, CAN, SOY, or MIX), cow within treatment, and residual error. Relationships between the intake of oleic or linoleic acid and concentrations of cis $9-18: 1,18: 2 \mathrm{n}-6$, trans11-18:1, or cis9,trans11-18:2 in blood plasma phos- pholipids, triglycerides, and free fatty acids were obtained using the REG procedure of SAS [34]. Relationships obtained from regression analysis were deemed linear or curvilinear based on coefficient of determinations. Differences between treatment means were determined by Tukey's studentized procedure, and were accepted as significantly different at $P<0.05$. One cow in the group fed soybean oil was omitted from the statistical analysis, because she inadvertently had access to the control diet for $2 \mathrm{~d}$ before sampling at $28 \mathrm{~d}$.

\section{RESULTS AND DISCUSSION}

A recent review indicated that as the percentage of unsaturated oil supplementation in the diet of lactating cows increases above $35 \mathrm{~g} \cdot \mathrm{kg}^{-1}$ dry matter, feed intake is depressed [7]. The level of oil supplementation in the present study was adequate to increase daily intake of total fatty acids by $426 \mathrm{~g} \cdot \mathrm{d}^{-1}$ without affecting dry matter intake (Tab. II). On average, cows fed supplemental oil consumed greater amounts of 16:0 $\left(22 \mathrm{~g} \cdot \mathrm{d}^{-1}\right)$, 18:0 (15 $\left.\mathrm{g} \cdot \mathrm{d}^{-1}\right)$, cis9-18:1 (239 $\left.\mathrm{g} \cdot \mathrm{d}^{-1}\right)$, $18: 2 \mathrm{n}-6\left(131 \mathrm{~g} \cdot \mathrm{d}^{-1}\right)$, and 18:3n-3 $\left(19 \mathrm{~g} \cdot \mathrm{d}^{-1}\right)$ compared with controls. In addition, cows fed CAN consumed 386 g more cis9-18:1, whereas cows fed SOY consumed $222 \mathrm{~g} \cdot \mathrm{d}^{-1}$ more 18:2n-6 compared with NOS-fed cows. Feeding MIX also increased cis $9-18: 1$ and 18:2n- 6 intake by 253 and $152 \mathrm{~g} \cdot \mathrm{d}^{-1}$ compared with NOS. Fatty acid intakes in this study were comparable with those indicated in previous reports concerning high-oleic or high-linoleic oil fed to lactating cows [19, 35, 37].

Milk production and milk fat percentage (data not shown) were not affected by 
Table II. Intake of dry matter and fatty acids by Jersey cows fed a control (NOS) diet or the control diet supplemented with $35 \mathrm{~g} \cdot \mathrm{kg}^{-1}$ dry matter canola oil (CAN), soybean oil (SOY), or equal amounts of canola and soybean oils (MIX).

\begin{tabular}{lrrrrr}
\hline & NOS & CAN & MIX & SOY & SEM \\
\hline Dry matter intake, $\mathrm{kg} \cdot \mathrm{d}^{-1}$ & 17.1 & 17.5 & 17.3 & 15.5 & 1.1 \\
Fatty acid intake, $\mathrm{g} \cdot \mathrm{d}^{-1}$ & & & & & \\
$14: 0$ & 3.7 & 4.2 & 3.3 & 4.0 & 0.2 \\
$16: 0$ & $112.7^{\mathrm{b}}$ & $116.2^{\mathrm{a}, \mathrm{b}}$ & $141.8^{\mathrm{a}}$ & $145.5^{\mathrm{a}}$ & 8.0 \\
$18: 0$ & $14.8^{\mathrm{c}}$ & $24.9^{\mathrm{b}}$ & $31.7^{\mathrm{a}}$ & $31.9^{\mathrm{a}}$ & 1.5 \\
cis9-18:1 & $104.7^{\mathrm{d}}$ & $490.8^{\mathrm{a}}$ & $357.7^{\mathrm{b}}$ & $184.4^{\mathrm{c}}$ & 19.2 \\
$18: 2 \mathrm{n}-6$ & $296.3^{\mathrm{c}}$ & $314.4^{\mathrm{c}}$ & $448.3^{\mathrm{b}}$ & $518.2^{\mathrm{a}}$ & 23.1 \\
$18: 3 \mathrm{n}-3$ & $83.8^{\mathrm{b}}$ & $87.2^{\mathrm{b}}$ & $107.9^{\mathrm{a}}$ & $112.6^{\mathrm{a}}$ & 5.9 \\
Total & $616.1^{\mathrm{b}}$ & $1037.6^{\mathrm{a}}$ & $1090.6^{\mathrm{a}}$ & $996.7^{\mathrm{a}}$ & 56.5 \\
\hline
\end{tabular}

a,b,c,d Least squares means within row and treatment category with different superscripts differ $(P<0.05)$.

treatments and averaged 22.1 vs. $23.6 \pm$ $1.7 \mathrm{~kg} \mathrm{milk} \cdot \mathrm{d}^{-1}$, and $4.7 \mathrm{vs} .4 .9 \pm 0.4 \%$ fat when NOS or oil-supplemented diets were fed, respectively. However, the numerically higher milk yield and fat percentage in oil-fed cows resulted in higher milk fat yield compared with NOS $\left(1.0 \mathrm{vs} .1 .2 \pm 0.1 \mathrm{~kg} \cdot \mathrm{d}^{-1}\right)$.

Total fatty acid concentration in plasma lipid fractions from oil-fed cows increased by $306 \mu \mathrm{g} \cdot \mathrm{mL}^{-1}(48 \%)$ compared with NOS, and reflected higher intake of fatty acids (Fig. 1). The supplemental fatty acids were distributed primarily in the PL, CE, and TG fractions, which increased by 142 (47\%), $144(57 \%)$, and $26(72 \%) \mu \mathrm{g} \cdot \mathrm{mL}^{-1}$, respectively. Higher amounts of PL, CE, and TG in blood plasma were reported previously when soybean oil, or oleic acid were fed to lactating cows $[19,31,35]$. Presumably an increase in the concentration of the major plasma lipid fractions is an obligatory response to accommodate transport of greater amounts of unsaturated and total fatty acids absorbed from the small intestine [5].

Overall, the average amount of fatty acids in the FFA fraction from oil-fed cows was similar to NOS, but this was due to the lower amount $(48 \%)$ of FFA in cows fed MIX compared with those fed CAN or SOY. Other reports indicated no changes $[19,35]$ or increases $[31,37]$ in the concentration of FFA in plasma when oils or hydrolyzed fat were fed to lactating cows. In the latter case, it was suggested that higher levels of FFA were a reflection of increased TG concentration and hydrolysis when supplemental fat was fed [31].

Intake of cis $9-18: 1$ and $18: 2 \mathrm{n}-6$ due to oil supplementation was the major factor leading to changes in the distribution of cis9-18:1, 18:2n-6, trans11-18:1, and cis 9 ,trans 11-18:2 in lipid fractions. Relative to basal (NOS), increases in the concentration of cis9-18:1 (100 to $155 \mathrm{mg} \cdot \mathrm{g}^{-1}$ of total fatty acids) and 18:2n-6 (327 to $369 \mathrm{mg} \cdot \mathrm{g}^{-1}$ ) in PL (Tab. III) corresponded with additional intake of these fatty acids when CAN or SOY were fed (Tab. II). The increase in trans 11-18:1 (12 to $\left.31 \mathrm{mg} \cdot \mathrm{g}^{-1}\right)$

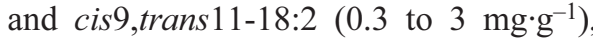
however, was related with higher 18:2n-6 intake when SOY was fed. Linoleic acid accounted for $684 \mathrm{mg} \cdot \mathrm{g}^{-1}$ in the $\mathrm{CE}$ fraction 


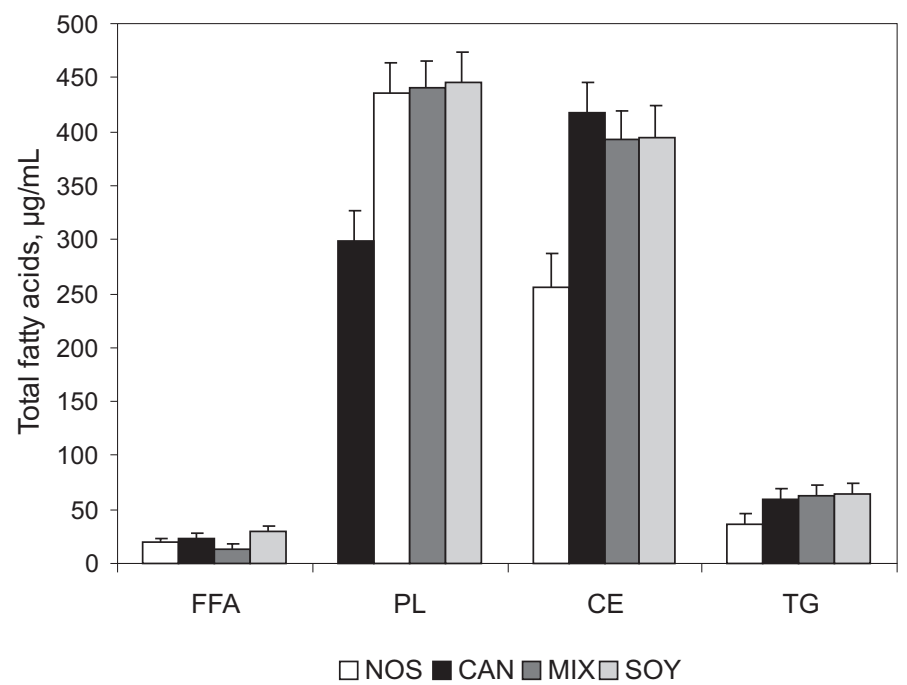

Figure 1. Total fatty acid concentration in blood plasma free fatty acids (FFA), phospholipids (PL), cholesterol esters (CE), and triglycerides (TG) from Jersey cows fed a control diet (NOS) or the control diet supplemented at $35 \mathrm{~g} \cdot \mathrm{kg}^{-1}$ dry matter with canola oil (CAN), soybean oil (SOY), or an equal mixture of canola and soybean oil (MIX). Feeding supplemental oils increased $(P<0.05)$ total fatty acid content in blood plasma PL, CE, and TG compared with the control diet.

(Tab. III) of cows fed NOS, but the proportion increased to $748 \mathrm{mg} \cdot \mathrm{g}^{-1}$ in cows fed SOY. Trans $11-18: 1$ (0 to $\left.2.2 \mathrm{mg} \cdot \mathrm{g}^{-1}\right)$ and cis 9 ,trans $11-18: 2$ ( 0 to $\left.1.5 \mathrm{mg} \cdot \mathrm{g}^{-1}\right)$ in $\mathrm{CE}$ also were increased by feeding SOY. A marked increase in the concentration of trans 11-18:1 (40 to $125 \mathrm{mg} \cdot \mathrm{g}^{-1}$ ) and cis9-18:1 (103 to $165 \mathrm{mg} \cdot \mathrm{g}^{-1}$ ) in $\mathrm{TG}$ (Tab. IV) also was evident when SOY or CAN were fed compared with NOS. Cis9,trans 11-18:2 in plasma TG of cows fed NOS was $1.4 \mathrm{mg} \cdot \mathrm{g}^{-1}$, but it increased to 7.4 or $12.4 \mathrm{mg} \cdot \mathrm{g}^{-1}$ in response to feeding CAN and MIX or SOY. In FFA, feeding SOY increased $18: 2 \mathrm{n}-6\left(37\right.$ to $\left.55 \mathrm{mg} \cdot \mathrm{g}^{-1}\right)$, trans11-18:1 (51 to $\left.84 \mathrm{mg} \cdot \mathrm{g}^{-1}\right)$, and cis 9 , trans $11-18: 2$ ( 0 to $\left.21 \mathrm{mg} \cdot \mathrm{g}^{-1}\right)$. In contrast, feeding CAN increased cis9-18:1 (153 to $195 \mathrm{mg} \cdot \mathrm{g}^{-1}$ ) (Tab. IV). Only feeding SOY altered 18:0 concentration by causing its decrease in PL (223 to $206 \mathrm{mg} \cdot \mathrm{g}^{-1}$ ) and TG (469 to $380 \mathrm{mg} \cdot \mathrm{g}^{-1}$ ).

Results suggest that some selectivity exists regarding the distribution of absorbed unsaturated fatty acids in the major plasma lipid fractions of cows fed oil. This selectivity becomes important when appraising the fatty acid contribution of lipid fractions to the mammary gland for milk fat synthesis. For example, fractional removal rate of fatty acids from plasma TG (of VLDL and chylomicra) in lactating cows is very rapid compared with the remaining LDL fraction [30] such that, during passage of blood from through the udder, it was estimated that $70 \%$ of plasma TG were hydrolyzed and their fatty acids made available for milk fat synthesis [9]. At high arterial concentrations, PL also provided fatty acids for milk fat synthesis [24, 38]. Therefore, it seems reasonable that the mammary gland could utilize non-esterified fatty acids derived from TG and PL when their concentrations in plasma are increased in response to oil feeding.

Greater concentrations of cis $9-18: 1$ and 18:2n-6 were found in all major lipid fractions when CAN or SOY was fed in this 
Table III. Concentration of fatty acids in the phospholipid and cholesterol ester fractions of blood plasma from Jersey cows fed a control (NOS) diet or the control diet supplemented with $35 \mathrm{~g} \cdot \mathrm{kg}^{-1} \mathrm{dry}$ matter canola oil (CAN), soybean oil (SOY), or equal amounts of canola and soybean oils (MIX).

\begin{tabular}{|c|c|c|c|c|c|}
\hline & NOS & CAN & MIX & SOY & SEM \\
\hline Fatty acid & \multicolumn{5}{|c|}{$\mathrm{mg} \cdot \mathrm{g}^{-1}$ total fatty acids } \\
\hline \multicolumn{6}{|l|}{ Phospholipid } \\
\hline $\begin{array}{l}14: 0 \\
\text { cis } 9-14: 1 \\
15: 0 \\
16: 0 \\
\text { cis } 9-16: 1 \\
17: 0 \\
18: 0 \\
\text { trans } 11-18: 1 \\
\text { cis } 9-18: 1 \\
18: 2 \mathrm{n}-6 \\
\text { cis } 9, \text { trans } 11-18: 2 \\
18: 3 \mathrm{n}-3 \\
20: 3 \mathrm{n}-3 \\
\text { Other }\end{array}$ & $\begin{array}{r}2.5^{\mathrm{a}} \\
3.1^{\mathrm{a}} \\
7.9^{\mathrm{a}} \\
140.5^{\mathrm{a}} \\
7.5^{\mathrm{a}} \\
17.1^{\mathrm{a}} \\
222.9^{\mathrm{a}} \\
12.0^{\mathrm{c}} \\
100.3^{\mathrm{b}} \\
327.4^{\mathrm{c}} \\
0.3^{\mathrm{d}} \\
27.9^{\mathrm{a}} \\
48.5^{\mathrm{a}} \\
81.9^{\mathrm{a}}\end{array}$ & $\begin{array}{r}2.1^{\mathrm{b}} \\
2.3^{\mathrm{b}} \\
6.7^{\mathrm{b}} \\
128.2^{\mathrm{b}} \\
5.4^{\mathrm{b}} \\
11.8^{\mathrm{b}} \\
226.5^{\mathrm{a}} \\
12.3^{\mathrm{c}} \\
151.1^{\mathrm{a}} \\
303.5^{\mathrm{d}} \\
1.2^{\mathrm{c}} \\
25.3^{\mathrm{a}} \\
43.0^{\mathrm{b}} \\
80.6\end{array}$ & $\begin{array}{r}1.8^{\mathrm{b}} \\
2.4^{\mathrm{b}} \\
6.8^{\mathrm{b}} \\
134.4^{\mathrm{a}} \\
5.5^{\mathrm{b}} \\
12.0^{\mathrm{b}} \\
215.3^{\mathrm{a}} \\
17.2^{\mathrm{b}} \\
105.2^{\mathrm{b}} \\
353.1^{\mathrm{b}} \\
2.0^{\mathrm{b}} \\
23.8^{\mathrm{a}} \\
41.1^{\mathrm{b}} \\
79.4\end{array}$ & $\begin{array}{r}2.0^{\mathrm{b}} \\
2.1^{\mathrm{b}} \\
6.8^{\mathrm{b}} \\
130.5^{\mathrm{a}} \\
5.2^{\mathrm{b}} \\
11.4^{\mathrm{b}} \\
206.3^{\mathrm{b}} \\
26.9^{\mathrm{a}} \\
97.7^{\mathrm{b}} \\
366.3^{\mathrm{a}} \\
3.1^{\mathrm{a}} \\
20.1^{\mathrm{b}} \\
41.1^{\mathrm{b}} \\
80.5^{\mathrm{a}}\end{array}$ & $\begin{array}{l}0.1 \\
0.2 \\
0.2 \\
3.4 \\
0.4 \\
0.4 \\
4.1 \\
1.1 \\
3.8 \\
6.2 \\
0.2 \\
1.0 \\
2.0 \\
\cdots\end{array}$ \\
\hline \multicolumn{6}{|l|}{ Cholesterol ester } \\
\hline $\begin{array}{l}14: 0 \\
\text { cis } 9-14: 1 \\
15: 0 \\
16: 0 \\
\text { cis } 9-16: 1 \\
17: 0 \\
18: 0 \\
\text { trans } 11-18: 1 \\
\text { cis } 9-18: 1 \\
18: 2 \mathrm{n}-6 \\
\text { cis } 9, \text { trans } 11-18: 2 \\
18: 3 \mathrm{n}-3 \\
20: 3 \mathrm{n}-3 \\
\text { Other }\end{array}$ & $\begin{array}{c}9.1^{\mathrm{a}} \\
16.9^{\mathrm{a}} \\
11.1^{\mathrm{a}} \\
44.9^{\mathrm{a}} \\
15.0^{\mathrm{a}} \\
2.7^{\mathrm{a}} \\
7.9^{-9} \\
\mathrm{ND}^{1} \\
35.4^{\mathrm{b}} \\
683.5^{\mathrm{b}} \\
\mathrm{ND} \\
99.9^{\mathrm{a}} \\
6.9^{\mathrm{a}} \\
23.4\end{array}$ & $\begin{array}{r}7.7^{\mathrm{b}} \\
13.8^{\mathrm{b}} \\
9.6^{\mathrm{b}} \\
37.5^{\mathrm{b}} \\
15.0^{\mathrm{a}} \\
1.6^{\mathrm{b}} \\
7.0^{\mathrm{b}} \\
1.1^{\mathrm{b}} \\
53.1^{\mathrm{a}} \\
682.6^{\mathrm{b}} \\
0.1^{\mathrm{b}} \\
105.4^{\mathrm{a}} \\
6.3^{\mathrm{a}} \\
236^{6}\end{array}$ & $\begin{array}{r}7.7^{\mathrm{b}} \\
12.1^{\mathrm{c}} \\
8.3^{\mathrm{b}} \\
35.9^{\mathrm{b}} \\
11.7^{\mathrm{b}} \\
1.6^{\mathrm{b}} \\
7.3^{\mathrm{b}} \\
1.4^{\mathrm{b}} \\
34.7^{\mathrm{b}} \\
735.5^{\mathrm{a}} \\
0.4^{\mathrm{b}} \\
76.9^{\mathrm{m}} \\
5.7^{\mathrm{b}} \\
22.1\end{array}$ & $\begin{array}{r}7.2^{\mathrm{b}} \\
11.0^{\mathrm{c}} \\
8.5^{\mathrm{b}} \\
36.0^{\mathrm{b}} \\
11.9^{\mathrm{b}} \\
1.1^{\mathrm{b}} \\
6.8^{\mathrm{a}} \\
2.2^{\mathrm{a}} \\
30.2^{\mathrm{c}} \\
744.3^{\mathrm{a}} \\
1.5^{\mathrm{a}} \\
77.3^{\mathrm{b}} \\
5.4^{\mathrm{b}} \\
22.6\end{array}$ & $\begin{array}{l}0.4 \\
0.6 \\
0.3 \\
1.1 \\
1.0 \\
0.2 \\
0.5 \\
0.3 \\
1.4 \\
7.0 \\
0.2 \\
8.5 \\
0.3\end{array}$ \\
\hline
\end{tabular}

${ }^{1}$ Not detected.

a,b,c,d Least squares means within row and treatment category with different superscripts differ $(P<0.05)$.

study compared with NOS. Linoleic acid was preferentially incorporated into PL and CE [5], but under conditions where large amounts of unsaturates are absorbed from the small intestine the rate of synthesis of PL may be insufficient to accommodate the increased supply of these fatty acids and extensive incorporation into TG also can occur. In vitro data indicated that $18: 2 n-6$ and 18:3n-3, but not cis $9-18: 1$, are the preferred substrates for the synthesis of CE in bovine plasma via the lecithin: cholesterol acyl transferase enzyme system [25]. This was consistent with the data of Moore et al. [21] which reported increased concentrations of 18:2n-6 and 18:3n-3 in plasma PL and CE of sheep following ruminal infusion of primarily linoleic or linolenic acid. We 
Table IV. Concentration of fatty acids in the triglyceride and free fatty acid fractions of blood plasma from Jersey cows fed a control (NOS) diet or the control diet supplemented with $35 \mathrm{~g} \cdot \mathrm{kg}^{-1}$ dry matter canola oil (CAN), soybean oil (SOY), or equal amounts of canola and soybean oils (MIX).

\begin{tabular}{|c|c|c|c|c|c|}
\hline & NOS & CAN & MIX & SOY & SEM \\
\hline Fatty acid & \multicolumn{5}{|c|}{$\mathrm{mg} \cdot \mathrm{g}^{-1}$ total fatty acids } \\
\hline \multicolumn{6}{|l|}{ Triglyceride } \\
\hline $14: 0$ & 34.1 & 32.7 & 28.5 & 30.5 & 4.5 \\
\hline $15: 0$ & $6.9^{\mathrm{a}}$ & $3.7^{\mathrm{b}}$ & $3.3^{\mathrm{b}}$ & $4.8^{\mathrm{b}}$ & 0.7 \\
\hline $16: 0$ & $263.1^{\mathrm{a}}$ & $219.3^{\mathrm{b}}$ & $226.1^{\mathrm{b}}$ & $240.3^{b}$ & 6.6 \\
\hline 18:0 & $468.8^{\mathrm{a}}$ & $423.1^{\mathrm{b}}$ & $430.8^{\mathrm{b}}$ & $379.5^{\mathrm{c}}$ & 19.5 \\
\hline trans $11-18: 1$ & $40.4^{\mathrm{d}}$ & $58.9^{\mathrm{c}}$ & $71.5^{\mathrm{b}}$ & $105.2^{\mathrm{a}}$ & 4.1 \\
\hline cis $9-18: 1$ & $102.8^{\mathrm{c}}$ & $161.2^{\mathrm{a}}$ & $132.3^{\mathrm{b}}$ & $100.7^{\mathrm{c}}$ & 5.2 \\
\hline $18: 2 n-6$ & $41.9^{\mathrm{c}}$ & $58.7^{\mathrm{b}}$ & $59.3^{\mathrm{b}}$ & $71.5^{\mathrm{a}}$ & 3.9 \\
\hline cis 9, trans $11-18: 2$ & $1.4^{\mathrm{c}}$ & $6.7^{\mathrm{b}}$ & $8.0^{\mathrm{b}}$ & $12.4^{\mathrm{a}}$ & 0.9 \\
\hline $18: 3 n-3$ & 9.9 & 7.7 & 5.8 & 8.8 & 1.8 \\
\hline Other & 30.7 & 28.0 & 28.4 & 28.3 & $\ldots$ \\
\hline \multicolumn{6}{|l|}{ Free fatty acid } \\
\hline $14: 0$ & 42.0 & 36.6 & 35.8 & 28.6 & 4.2 \\
\hline cis $9-14: 1$ & 9.7 & 6.6 & 8.7 & 10.0 & 1.4 \\
\hline $16: 0$ & $274.0^{\mathrm{a}}$ & $248.1^{\mathrm{b}}$ & $240.9^{\mathrm{b}}$ & $242.9^{\mathrm{b}}$ & 8.3 \\
\hline cis $9-16: 1$ & 7.2 & 12.9 & 10.7 & 9.1 & 2.4 \\
\hline $17: 0$ & $11.4^{\mathrm{a}}$ & $8.5^{\mathrm{b}}$ & $8.3^{\mathrm{b}}$ & $9.1^{\mathrm{b}}$ & 0.6 \\
\hline $18: 0$ & 356.2 & 331.7 & 339.7 & 342.2 & 11.3 \\
\hline trans $11-18: 1$ & $45.3^{\mathrm{b}}$ & $61.4^{\mathrm{b}}$ & $84.0^{\mathrm{a}}$ & $83.8^{\mathrm{a}}$ & 8.4 \\
\hline cis9-18:1 & $152.5^{\mathrm{b}}$ & $194.5^{\mathrm{a}}$ & $174.5^{\mathrm{b}}$ & $132.1^{\mathrm{b}}$ & 12.7 \\
\hline $18: 2 n-6$ & $37.1^{\mathrm{b}}$ & $33.8^{\mathrm{b}}$ & $35.0^{\mathrm{b}}$ & $55.1^{\mathrm{a}}$ & 5.7 \\
\hline cis 9, trans $11-18: 2$ & $\mathrm{ND}^{1}$ & $4.1^{\mathrm{b}}$ & $5.5^{\mathrm{b}}$ & $20.5^{\mathrm{a}}$ & 2.4 \\
\hline $18: 3 n-3$ & 13.1 & 10.6 & 9.8 & 8.4 & 1.6 \\
\hline $20: 3 n-3$ & 9.3 & 8.9 & 5.9 & 17.1 & 4.3 \\
\hline Other & 42.2 & 42.3 & 41.2 & 41.1 & $\ldots$ \\
\hline
\end{tabular}

${ }^{1}$ Not detected.

a,b,c Least squares means within row and treatment category with different superscripts differ $(P<0.05)$.

found that as the level of supplemental 18:2n-6 intake increased (Fig. 2A), the incorporation of linoleic acid into all lipid fractions also increased linearly $\left(\mathrm{R}^{2}=0.69\right.$, $P<0.001)$. Intake of cis9-18:1 also was a good predictor $\left(\mathrm{R}^{2}=0.52, P<0.001\right)$ of oleic acid incorporation into plasma FFA, TG, and PL (Fig. 2B). Greater absorption of cis9-18:1 when CAN was fed may have increased the amount of this fatty acid esterified to plasma lecithin, thus elevating its proportion in PL.
Daily abomasal infusion of 0 to $400 \mathrm{~g}$ high-oleic sunflower oil (86\% cis9-18:1) linearly increased blood plasma TG and oleic acid percentage in TG [17]. The concentration of FFA tended to increase $(P=$ 0.08 ) as the rate of cis9-18: 1 infusion increased, but no clear pattern could be observed. As with PL, our data indicated that cis 9-18:1 content of TG was a reflection of dietary oleic acid intake. It appears that significant amounts of dietary cis9-18:1 escaped biohydrogenation in the rumen 


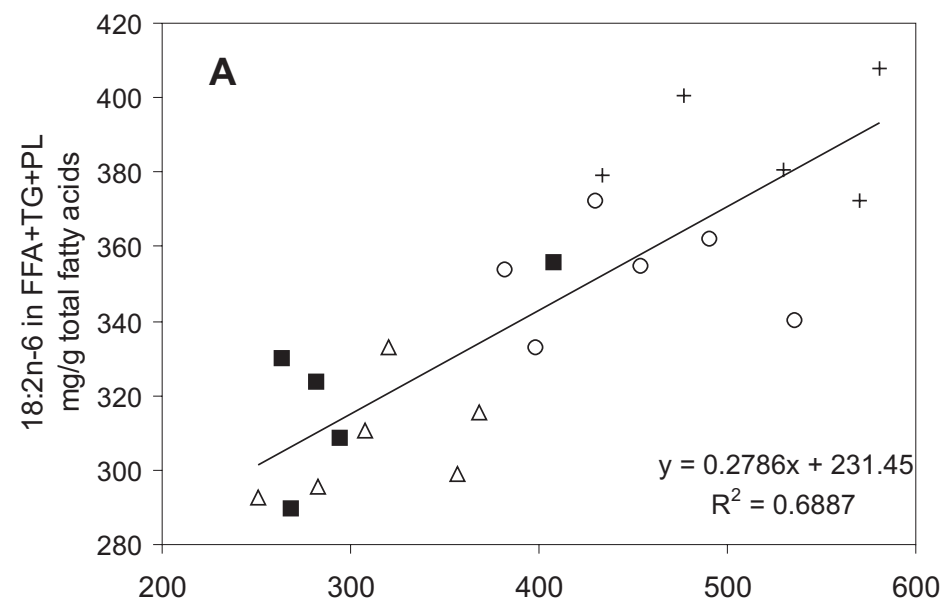

$18: 2 n-6$ intake, $g / d$

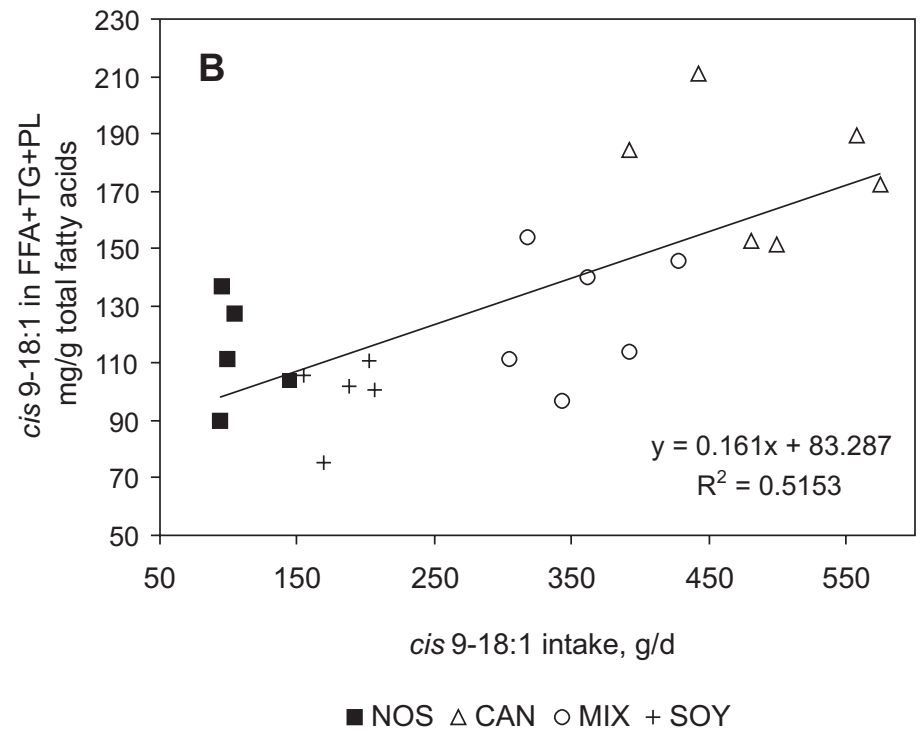

Figure 2. Relationships between linoleic acid intake and linoleic acid concentration (Panel A), or between oleic acid intake and oleic acid concentration (Panel B) in plasma free fatty acids (FFA), phospholipids (PL) and triglycerides (TG) (as a proportion of total plasma fatty acids) from Jersey cows fed a control diet (NOS) or the control diet supplemented at $35 \mathrm{~g} \cdot \mathrm{kg}^{-1}$ dry matter with canola oil (CAN), soybean oil (SOY), or an equal mixture of canola and soybean oil (MIX).

resulting in a higher percentage of this fatty acid in plasma PL, TG, and FFA. We did not find a relationship between unsaturated fatty acid intake and 18:0 concentration in lipid fractions (data not shown) which may indicate that, biohydrogenation of unsaturated fatty 
acids was not complete or that there was significant desaturation of stearic acid in peripheral tissues and small intestine.

It is well established that a portion of dietary $18: 2 n-6$ and $18: 3 n-3$ is hydrogenated in the rumen $[15,16,33]$, mainly to trans11-18:1 and(or) 18:0. Incomplete biohydrogenation of $18: 2 \mathrm{n}-6$ also results in the production of conjugated fatty acids, of which cis 9 ,trans 11-18:2 is the predominant isomer [15]. The major Gram-positive ruminal bacterium, Butyrivibrio fibrisolvens, has the capacity to hydrogenate linoleic acid only to trans 11-18:1. Apparently, two distinct microbial populations in the rumen are involved in the complete biohydrogenation of 18: $2 n-6$ to $18: 0$, with the hydrogenation of trans 11-18:1 to $18: 0$ being the rate-limiting step [14]. Thus, diets containing supplemental unsaturated fatty acids increase flow and intestinal absorption of fatty acid intermediates derived from the ruminal biohydrogenation process.

Feeding SOY in the present study increased trans11-18:1 concentration in plasma to the greatest extent. O'Kelly and Spiers [28] observed increased proportions of trans 11-18:1 in PL and TG when steers were fed safflower oil. An exponential relationship $\left(\mathrm{R}^{2}=0.69, P<0.001\right)$ between 18:2n-6 intake and concentrations of trans 11-18:1 in FFA, TG, and PL fractions provided the best fit for our data (Fig. 3A). This response indicates that the extent of hydrogenation was less complete, more trans 11-18:1 accumulation, as dietary $18: 2 \mathrm{n}-6$ intake increased. Trans $11-18: 1$ is preferentially incorporated into the sn- 1 position of PL [5], but substantial enrichment in the $\mathrm{CE}$ and $\mathrm{TG}$ fractions also occurred when human diets were supplemented with a mixture of trans-fatty acids [39].

Absorption of cis9,trans11-18:2 or trans 10,cis 12-18:2 through the lymphatic pathway of rats averaged $96 \%$ and was similar to $18: 2 n-6$ [20]. This may explain why transfer of CLA isomers to the mammary gland for its incorporation into milk fat triglycerides is relatively rapid [18]. Abomasal infusion of CLA linearly increased the percentage of CLA in plasma TG, PL, and milk fat within $24 \mathrm{~h}$ [18]. During CLA infusion, there was a positive relationship between the percentage of CLA in plasma TG and PL with CLA percentage in milk fat.

Similar to trans11-18:1, feeding SOY increased concentrations of cis 9 ,trans 11 18:2 to the greatest extent in the plasma fractions studied (Tabs. III and IV). Milk fat cis9,trans 11-18: 2 concentration (data not shown) also was higher when oils $\left(10 \mathrm{mg} \cdot \mathrm{g}^{-1}\right.$ of total fatty acids) were fed compared with NOS $\left(5 \mathrm{mg} \cdot \mathrm{g}^{-1}\right)$, but was highest in response to SOY $\left(14 \mathrm{mg} \cdot \mathrm{g}^{-1}\right)$. Feeding a mixture of cis,trans-conjugated dienoic fatty acids ( $5 \%$ of dietary energy) to humans doubled their concentrations in PL [39]. As with trans11-18:1, higher availability of cis 9,trans11-18:2 in the enterocyte could have increased its binding to lecithin for synthesis of PL via the LCAT enzyme system. Intake of $18: 2 n-6$ was positively related $\left(\mathrm{R}^{2}=0.57, P<0.001\right)$ with CLA concentrations in plasma fractions (Fig. 3B), but this relationship was not as strong as that between linoleic acid intake and trans 11-18:1 in blood plasma (Fig. 3A). It could be possible that a portion of trans 11-18:1 was desaturated to cis9,trans 11-18: 2 in the intestine [3]. The stronger relationship $\left(\mathrm{R}^{2}=\right.$ $0.65, P<0.001)$ between trans 11-18:1 and cis9,trans 11-18:2 in blood plasma (Fig. 4A) suggests that desaturation of ruminally derived trans 11-18:1 could be a source of endogenous cis9,trans11-18:2. Morales et al. [22] found a higher ratio of trans11-18:1 to cis9,trans11-18:2 in plasma TG of cows fed roasted soybeans, which was taken as an indication that some desaturation of rumen-derived trans11-18:1 had occurred. The contribution of intestinal $\Delta^{9}$ desaturase to cis9,trans 11-18:2 synthesis, however, has not been evaluated. Alternatively, the above relationships could simply 

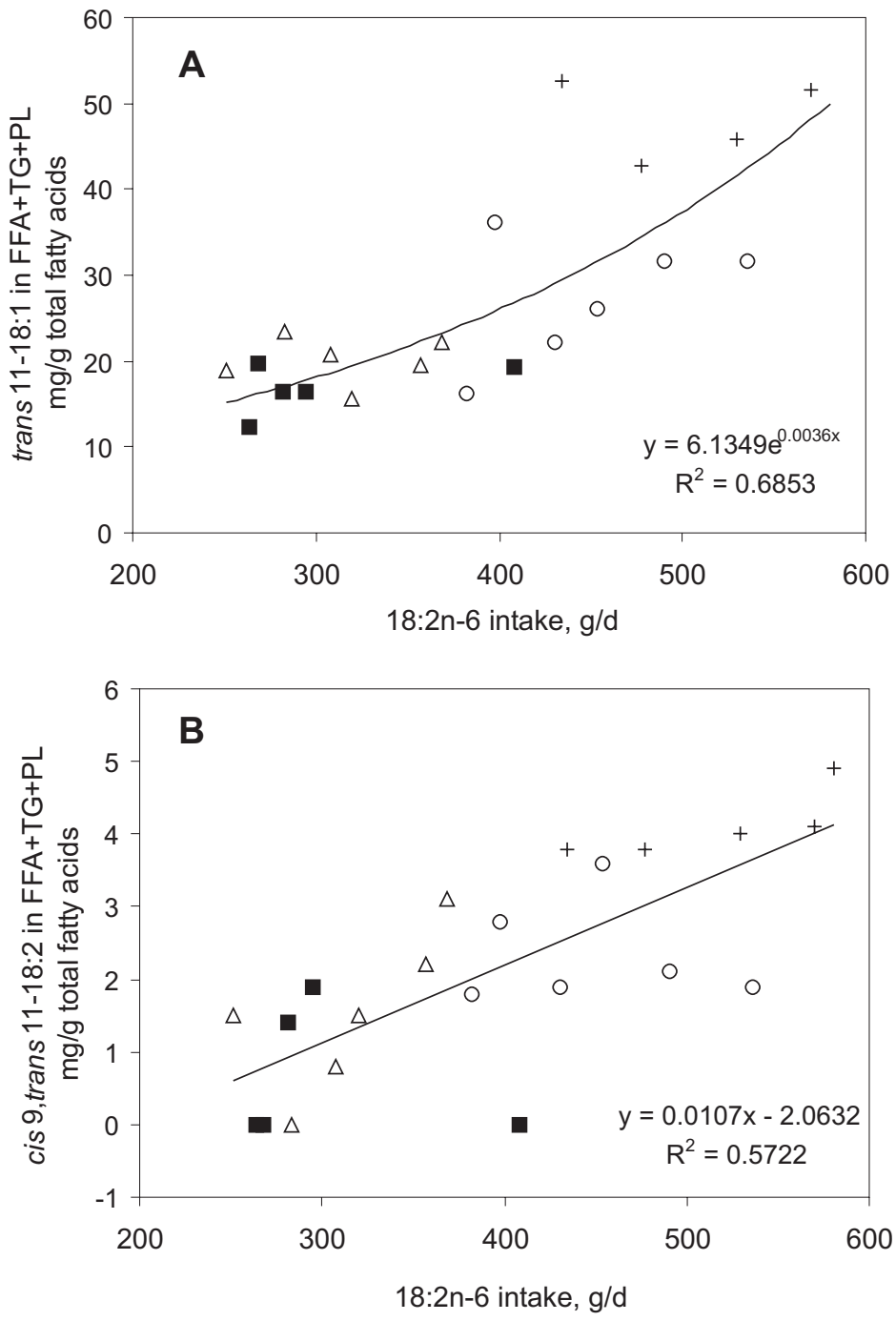

- NOS $\triangle \mathrm{CAN} O \mathrm{MIX}+\mathrm{SOY}$

Figure 3. Relationships between linoleic acid intake and trans-vaccenic acid (Panel A) or cis9, trans 11-CLA (Panel B) concentration in plasma free fatty acids (FFA), phospholipids (PL) and triglycerides (TG) (as a proportion of total plasma fatty acids) from Jersey cows fed a control diet (NOS) or the control diet supplemented at $35 \mathrm{~g} \cdot \mathrm{kg}^{-1}$ dry matter with canola oil (CAN), soybean oil (SOY), or an equal mixture of canola and soybean oil (MIX). 

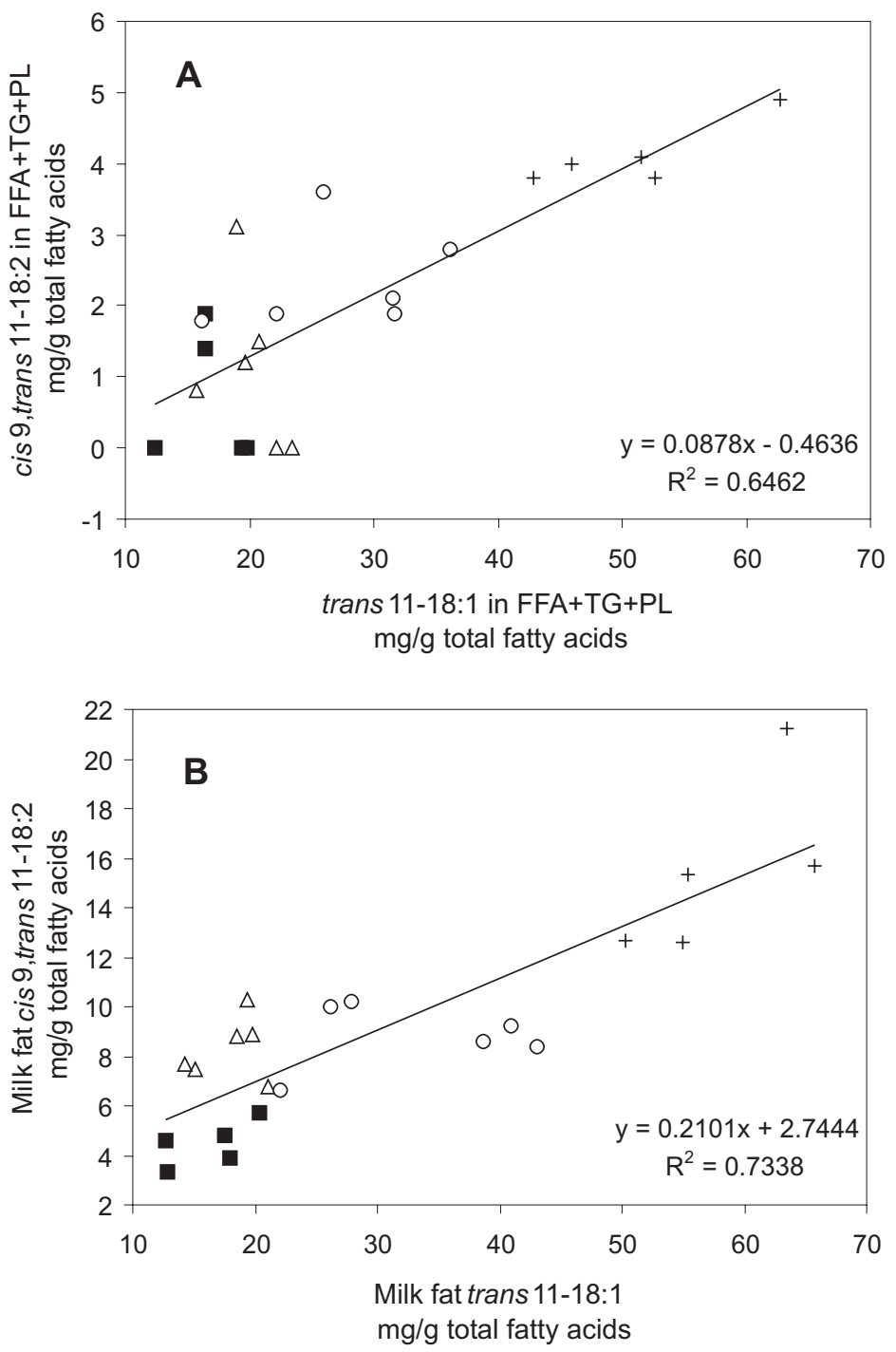

- NOS $\triangle \mathrm{CAN} O \mathrm{MIX}+\mathrm{SOY}$

Figure 4. Relationships between trans-vaccenic acid and cis9,trans 11-CLA concentrations in plasma free fatty acids (FFA), phospholipids (PL) and triglycerides (TG) (as a proportion of total plasma fatty acids) (Panel A), or in milk fat (Panel B) from Jersey cows fed a control diet (NOS) or the control diet supplemented at $35 \mathrm{~g} \cdot \mathrm{kg}^{-1}$ dry matter with canola oil (CAN), soybean oil (SOY), or an equal mixture of canola and soybean oil (MIX). 
indicate that partial biohydrogenation of cis9,trans11-18:2 to trans11-18:1 in the rumen caused greater intestinal flow, absorption, and availability of both fatty acids in blood for uptake by tissues.

Mammary gland absorption of cis 9 , trans11-18:2 and trans11-18:1 from plasma and incorporation into milk fat appeared to be substantial. The yield (data not shown) of trans11-18:1 increased from $13.7 \mathrm{~g} \cdot \mathrm{d}^{-1}$ when feeding NOS to $16.8,37.2$, or $43.1 \mathrm{~g} \cdot \mathrm{d}^{-1}$ in response to feeding CAN, MIX, or SOY, respectively. Similarly, cis9,trans 11-18:2 yield in milk fat was $3.8 \mathrm{~g} \cdot \mathrm{d}^{-1}$ when NOS was fed compared with 7.3, 7.7, or $11.2 \mathrm{~g} \cdot \mathrm{d}^{-1}$ when CAN, MIX, or SOY were fed, respectively. A positive correlation $\left(\mathrm{R}^{2}=0.73, P<0.001\right)$ between trans 11-18:1 and cis9, trans11-18:2 in milk fat (Fig. 4B) may indicate that the mammary gland could readily take up both fatty acids from blood and(or) synthesize CLA from trans 11-18:1. When bovine mammary cells were incubated with trans11-18:1 compared with cis $9-18: 1,18: 2 \mathrm{n}-6$, or cis 9 ,trans 11-18:2, there was an increase in $\Delta^{9}$-desaturase activity and mRNA abundance [10]. Indeed, a 55\% increase in milk cis 9 ,trans 11-18:2 concentration in response to abomasal infusion of trans11-18:1 suggests that desaturation of trans11-18:1 is feasible [8].

Stearic acid is one of the predominant fatty acids in blood plasma PL and TG of ruminants under normal dietary conditions [5], and its concentration may increase when plant oils with high cis9-18:1 content are fed [6, 35]. Morris [23] indicated that oleic and elaidic acid in the rumen are biohydrogenated directly to stearic acid without prior isomerization. Intake of cis9-18:1 from whole soybeans resulted in greater 18:0 concentration in plasma TG [22]. In our study, however, feeding SOY decreased 18:0 in PL and TG when compared with other treatments. A decrease in 18:0 concentration coupled with an increase in cis9,trans11-18:2 and trans11-18:1 are further indications that biohydrogenation was less complete as dietary 18:2n-6 intake increased. This also was reflected in the poor relationships (data not shown) between dietary cis9-18:1 and 18:2n-6 intake with plasma 18:0 concentrations.

In general, feeding supplemental oils reduced the concentrations of tetradecanoic, tetradecenoic, pentadecanoic, hexadecanoic, heptadecanoic, and eicosatrienoic acids. O'Kelly and Spiers [28], Jenkins et al. [12] and Jenkins [11] also found reduced concentrations of eicosatrienoic, pentadecanoic, and heptadecanoic acid when safflower or soybean oil were fed to ruminants, and suggested that oil supplementation reduced de novo lipid synthesis by ruminal microbes.

\section{CONCLUSIONS}

Feeding high-oleic or high-linoleic oils to ruminants enhances the amount of dietary oleic or linoleic acid that escapes biohydrogenation in the rumen. Thus, incorporation of these fatty acids into plasma triglycerides, cholesterol esters, and phospholipids increases. A portion of supplemental linoleic acid, however, is hydrogenated and enhances trans11-18:1 and cis9,trans1118:2 content of plasma lipid fractions and milk fat. Production of these isomers in the rumen is enhanced as linoleic acid intake increases, suggesting the capacity of microbes to hydrogenate may be overcome by high levels of unsaturated fatty acids. The overall result is greater concentration of trans11-18:1 and cis9,trans11-18:2 but lower 18:0 in plasma. Although indirectly, our results concur with previous data indicating that the mammary gland extracts cis9,trans 11-18:2 and trans11-18:1 bound to triglycerides and(or) phospholipids. However, more detailed studies of mammary gland extraction and uptake of trans-fatty acids from plasma lipid fractions are needed to confirm the contribution 
of blood phospholipids to the trans 11-18:1 and cis9,trans 11-18:2 content of milk fat.

\section{ACKNOWLEDGEMENTS}

The authors are grateful to Cargill Foods (Minneapolis, MN, USA) for donating the high-oleic canola oil used in this study. Partial funding for the study was provided by the Virginia Agricultural Council.

\section{REFERENCES}

[1] AOAC, Official Methods of Analysis, 15th ed., AOAC, Arlington, VA, 1990.

[2] Bandara A.B.P.A., Modifying fatty acid composition of bovine milk by abomasal infusion or dietary supplementation of seed oils or fish oil, Ph.D. Dissertation, Virginia Tech (1997).

[3] Bickerstaffe R., Annison E., Glycerokinase and desaturase activity in pig, chicken, and goat intestinal epithelium, Comp. Biochem. Physiol. 31 (1969) 47-54.

[4] Bitman J., Wood D., Lefcourt A., Rhythms in cholesterol, cholesteryl esters, free fatty acids, and triglycerides in blood of lactating dairy cows, J. Dairy Sci. 73 (1990) 948-955.

[5] Christie W., The effect of diet and other factors on the lipid composition of ruminant tissues and milk, in: Christie W. (Ed.), Lipid Metabolism in Ruminant Animals, Pergamon Press, England, 1981, pp. 193-226.

[6] Echelmeier S., DePeters E., Perez-Monti H., Taylor S., Effects of continuous infusions of canola oil into either the rumen or the abomasum of lactating dairy cows on milk composition and nutrient digestion, J. Anim. Sci. 76 (1998) (Suppl. 1) 301.

[7] Firkins J., Eastridge M., Assessment of the effects of iodine value on fatty acid digestibility, feed intake, and milk production, J. Dairy Sci. 77 (1994) 2357-2366.

[8] Griinari J., Corl B., Lacy S., Chouinard P., Nurmela K., Bauman D., Conjugated linoleic acid is synthesized endogenously in lactating dairy cows by $\Delta^{9}$ desaturase, J. Nutr. 130 (2000) 2285-2291.

[9] Glascock R., Welch V., Contribution of the fatty acids of three low density serum lipoproteins to bovine milk fat, J. Dairy Sci. 57 (1974) 1364 1370.

[10] Jayan G., Herbein J., "Healthier" dairy fat using trans-vaccenic acid, Nutr. Food Sci. 30 (2000) 304-309.
[11] Jenkins T., Butylsoyamide protects soybean oil from ruminal biohydrogenation: effects of butylsoyamide on plasma fatty acids and nutrient digestion in sheep, J. Anim. Sci. 73 (1995) 818-823.

[12] Jenkins T., Thies E., Fotouhi N., Dietary soybean oil changes lipolytic rate and composition of fatty acids in plasma membranes of ovine adipocytes, J. Nutr. 124 (1994) 566-570.

[13] Kaluzny M., Duncan L., Merritt M., Epps D., Rapid separation of lipid classes in high yield and purity using bonded phase columns, J. Lipid Res. 26 (1985) 135-140.

[14] Kemp P., White R., Lander D., The hydrogenation of unsaturated fatty acids by five bacterial isolates from the sheep rumen, including a new species, J. Gen. Microbiol. 90 (1975) 100-114.

[15] Kepler C., Hirons K., McNeill J., Tove S., Intermediates and products of the biohydrogenation of linoleic acid by Butyrivibrio fibrisolvens, J. Biol. Chem. 241 (1966) 1350-1354.

[16] Kepler C., Tove S., Biohydrogenation of unsaturated fatty acids, III. Purification and properties of a linoleate delta-12-cis,delta11-transisomerase from Butyrivibrio fibrisolvens, J. Biol. Chem. 242 (1967) 5686-5692.

[17] La Count D., Drackley J., Laesch S., Clark J., Secretion of oleic acid in milk fat in response to abomasal infusions of canola or high oleic sunflower fatty acids, J. Dairy Sci. 77 (1994) 11372-1385.

[18] Loor J., Herbein J., Exogenous conjugated linoleic acid isomers reduce bovine milk fat concentration and yield by inhibiting de novo fatty acids synthesis, J. Nutr. 128 (1998) 2411-2419.

[19] Macleod G., Wood A., Yao Y., Influence of dietary fat on rumen fatty acids, plasma lipid and milk fat composition in the cow, J. Dairy Sci. 55 (1972) 446-453.

[20] Martin J., Sebedio J., Caselli C., Pimont C., Martine L., Bernard A., Lymphatic delivery and in vitro pancreatic lipase hydrolysis of glycerol esters of conjugated linoleic acids in rats, J. Nutr. 130 (2000) 1108-1114.

[21] Moore J., Noble R., Steele W., Factors affecting the polyunsaturated fatty acid content of the plasma lipids of sheep, Brit. J. Nutr. 22 (1968) 681-688.

[22] Morales M., Palmquist D., Weiss W., Effects of fat source and copper on unsaturation of blood and milk triacylglycerol fatty acids in Holstein and Jersey cows, J. Dairy Sci. 83 (2000) 2105-2111.

[23] Morris L., Mechanisms and stereochemistry in fatty acid metabolism, Biochem. J. 118 (1970) 681-693.

[24] Nielsen M., Jakobsen K., Changes in mammary uptake of free fatty acids, triglyceride, cholesterol, and phospholipid in relation to milk 
synthesis during lactation in goats, Comp. Biochem. Physiol. A109 (1994) 857-967.

[25] Noble R., O'Kelly J., Moore J., Observations on the lecithin: cholesterol acyltransferase in bovine plasma, Biochim. Biophys. Acta 270 (1972) 519-528.

[26] Noble R., Steele W., Moore J., The incorporation of linoleic acid into the plasma lipids of sheep given intraruminal infusions of maize oil or free linoleic acid, Br. J. Nutr. 23 (1969) 709-714.

[27] NRC, Nutrient Requirements of Dairy Cattle, 6th rev. ed., Natl. Acad. Sci., Washington, DC, 1989 .

[28] O'Kelly J., Spiers W., Effects of supplementation with safflower oil on voluntary feed intake and tissue fatty acid composition of steers fed low quality hay ad libitum, Aust. J. Exp. Agric. 33 (1993) 693-697.

[29] O'Shea M., Devery R., Lawless F., Murphy J., Stanton C., Milk fat conjugated linoleic acid inhibits growth of human mammary MCF-7 cancer cells, Antican. Res. 20 (2000) 3591-3602.

[30] Palmquist D., A kinetic concept of lipid transport in ruminants. A review, J. Dairy Sci. 59 (1976) 355-363.

[31] Palmquist D., Conrad H., High fat rations for dairy cows effects on feed intake, milk and milk fat production, and plasma metabolism, J. Dairy Sci. 61 (1978) 890-901.

[32] Park P., Goins R., In situ preparation of fatty acid methyl esters for analysis of fatty acid composition in foods, J. Food Sci. 59 (1994) 1262-1266.
[33] Polan C., McNeill J., Tove S., Biohydrogenation of unsaturated fatty acids by rumen bacteria, J. Bacteriol. 88 (1964) 1056-1064.

[34] $\mathrm{SAS}^{\circledR}$, Version 8 Edition, SAS Inst., Inc., Cary, NC, 2000.

[35] Selner D., Schultz L., Effects of feeding oleic acid or hydrogenated vegetable oils to lactating cows, J. Dairy Sci. 63 (1980) 1235-1241.

[36] Stallings C., Kroll G., Kelley J., McGilliard M., A computer ration evaluation program for heifers, dry cows, and lactating cows, J. Dairy Sci. 68 (1985) 1015-1019.

[37] Tesfa A., Touri M., Syrjala-Quist L., The effects of increasing levels of rapeseed oil in the diets of lactating milking cows on milk yield, milk composition, blood and rumen metabolites, World Rev. Anim. Prod. 27 (1992) 34-40.

[38] Thivierge M., Chouinard P., Levesque J., Girard V., Seoane J., Brisson G., Effects of buffer on milk fatty acids and mammary arteriovenous differences in dairy cows fed Ca salts of fatty acids, J. Dairy Sci. 81 (1998) 2001-2010.

[39] Vidgren H., Louheranta A., Agren J., Schwab U., Uusitupa M., Divergent incorporation of dietary trans fatty acids in different serum lipid fractions, Lipids 33 (1998) 955-962.

[40] Van Soest P., Robertson J., Lewis B., Methods of dietary fiber, neutral detergent fiber, and nonstarch polysacharides in relation to animal nutrition, J. Dairy Sci. 74 (1991) 3583-3597. 